\title{
The Growth Hormone Affects the Brain Protein Synthesis Rate in Hypophysectomized Aged Rats
}

\author{
Miho OHsumi ${ }^{1}$, Kazuyo TujIOKA ${ }^{2}$, Kazutoshi HAYASE ${ }^{3}$, Shinichi NAGATA ${ }^{1}$ and \\ Hidehiko YoKOGOSHI ${ }^{1}$ \\ ${ }^{1}$ Laboratory of Nutritional Biochemistry, School of Food and Nutritional Sciences, COE Program in the 21st \\ Century, The University of Shizuoka, Yada, Suruga, Shizuoka 422-8526, Japan \\ ${ }^{2}$ Faculty of Early Childhood Care and Education, Ohkagakuen University, Toyoake, Aichi 470-1193, Japan \\ ${ }^{3}$ Department of Home Economics, Aichi University of Education, Kariya, Aichi, 448-8542, Japan
}

(Received July 17, 2007)

\begin{abstract}
Summary The purpose of this study was to determine whether the growth hormone (GH) affects the rate of brain protein synthesis in hypophysectomized aged rats. Experiments were conducted on three groups of 24-wk-old male rats: group 1 were hypophysectomized to reduce the level of plasma $\mathrm{GH}$, group 2 were hypophysectomized and treated with $\mathrm{GH}$ and group 3 were sham-operated controls. The fractional rates of protein synthesis in the brains of hypophysectomized rats with GH were significantly greater than those in hypophysectomized rats without $\mathrm{GH}$. In the cerebral cortex and cerebellum, the RNA activity [g protein synthesized/(g RNA $\cdot \mathrm{d})$ ] significantly correlated with the fractional rate of protein synthesis $(r>0.88, p<0.001)$. The RNA concentration (mg RNA/g protein) was also related to the fractional rate of protein synthesis in these organs $(r>0.56, p<0.05)$. The results suggest that the treatment of $\mathrm{GH}$ to hypophysectomized aged rats is likely to increase the rate of protein synthesis in the brain, and that RNA activity is at least partly related to the fractional rate of brain protein synthesis.
\end{abstract}

Key Words growth hormone, hypophysectomy, protein synthesis, brain, rats

The metabolic response to dietary proteins, age and hormonal factors includes marked changes in protein synthesis, especially in the liver, muscle and intestine (1-5). Protein synthesis in the brain is also sensitive to the alteration of dietary amino acid composition in young rats $(6,7)$.

Many investigators have reported that protein synthesis declined in specific tissues (e.g., liver or muscle) and in the whole body throughout development in mammals after weaning $(8-10)$. We demonstrated that the rate of protein synthesis in the brain decreased with age in rats after weaning (11). In many investigations, the protein synthesis in the brain and the concentration of plasma growth hormone $(\mathrm{GH})$ has been shown to depend on the quantity and quality of dietary protein in aged rats (12-14). GH has been known to increase tissue protein synthesis by stimulating translational activity (15). However, the role of $\mathrm{GH}$ in maintaining the rate of brain protein synthesis remains unknown under physiological conditions.

Recently, several investigators demonstrated that there were $\mathrm{GH}$ receptors in brain regions, and that $\mathrm{GH}$ had a direct affect on brain function (e.g., gene expression in neurons and memory) (16). The possibility that the hormone itself may pass the blood-brain barrier is supported by several studies (17). Therefore, the possible effects of $\mathrm{GH}$ on brain protein synthesis in hypophy-

*To whom correspondence should be addressed.

Abbreviation: GH, growth hormone. sectomized aged rats are of nutritional importance in understanding the role of protein nutrition in the brain function in mammals.

The purpose of our study was to determine whether the regulation of brain protein synthesis in aged rats was mediated through changes in the concentration of $\mathrm{GH}$ when the quantity and quality of dietary protein is manipulated. Thus, in the present study, the effect of $\mathrm{GH}$ treatment on the rates of brain protein synthesis were determined in hypophysectomized aged rats. In our previous report $(12,13)$, a positive correlation between the rate of protein synthesis and the RNA activity was found in the brain when the quality or quantity of dietary protein was manipulated in aged rats. However, the reduction with age in protein synthesis in the brain was related to a fall in the RNA concentration (11). Two questions were considered in the present study: 1) whether GH might affect the rate of brain protein synthesis in hypophysectomized aged rats, and 2) whether greater RNA concentration or RNA activity in hypophysectomized aged rats treated with $\mathrm{GH}$ resulted in a greater protein synthesis rate in the brain compared with untreated hypophysectomized rats. Therefore, we examined three indicators of protein synthesis in rat brains: its rate, RNA concentration and RNA activity. Hypophysectomized rats were studied as an animal model for GH deficiency $(18,19)$, and also used to test the function of GH. Thus, in this experiment, we used hypophysectomized male rats as the animals. 


\section{MATERIALS AND METHODS}

Chemicals. L-Tyrosine decarboxylase, L-leucyl-L-alanine and $\beta$-phenethylamine were purchased from Sigma Chemical (St. Louis, MO, USA). L- $\left[2,6-{ }^{3} \mathrm{H}\right]$ Phenylalanine $(1.5 \mathrm{TBq} / \mathrm{mmol})$ was obtained from GE Healthcare Bio-Sciences (Tokyo, Japan). All other reagents were purchased from Wako Pure Chemical (Osaka, Japan).

Animals and diet. Male 24-wk-old Wistar rats (Japan SLC, Hamamatsu, Japan) were individually housed at $24^{\circ} \mathrm{C}$ in a room with a 12-h light-dark cycle. The rats were fed a $20 \%$ casein diet (Table 1) after they had been fed a commercial nonpurified diet (MF; Oriental Yeast, Tokyo, Japan) for $1 \mathrm{~d}$. All rats were individually housed and given free access to food and water. The approval of Aichi University of Education Animal Care and Use Committee was given for our animal experiments.

Experimental design. The experiment was conducted on three groups of rats. All rats were fed the $20 \%$ casein diet for $16 \mathrm{~d}$. On day 1 , two groups were hypophysectomized and injected subcutaneously with either human growth hormone dissolved in saline [20 $\mu \mathrm{g} /(100 \mathrm{~g}$ body weight·d)] or saline for the last $7 \mathrm{~d}$ of the $16-\mathrm{d}$ experimental period. The sham-operated control group was administered the saline only for last $7 \mathrm{~d}$. After $16 \mathrm{~d}$, the fractional rates of protein synthesis in the brain were measured by the method of Garlick et al. (20). The rats were decapitated between 1000 and $1200 \mathrm{~h}$. Brain regions (21) were quickly removed and frozen in liquid nitrogen. The concentrations of protein and RNA in brain were measured according to the methods of Lowry et al. (22) with bovine serum albumin as a standard, and Fleck and Munro (23), respectively. The GH concentration in plasma was determined by EIA (Rat Growth Hormone Enzyme Immunoassay Kit; SPI bio, Massy, Cedex, France).

Fractional rate of protein synthesis in tissues. Radioactive L- $\left[2,6-{ }^{3} \mathrm{H}\right]$ phenylalanine was combined with unlabeled phenylalanine to yield a dose of $1.85 \mathrm{MBq}$ and a concentration of $150 \mathrm{mmol} / \mathrm{L}$ saline. Rats were restrained in a cloth and injected with the radioisotope via the tail vein at a dose of $1 \mathrm{~mL} / 100 \mathrm{~g}$ body weight

Table 1. Composition of basal diet.

\begin{tabular}{lc}
\hline \multicolumn{1}{c}{ Ingredient } & 20\% Casein \\
\hline & $(\mathrm{g} / 100 \mathrm{~g}$ of diet $)$ \\
Casein & 20.0 \\
L-Cystine & 0.3 \\
Cornstarch $^{1}$ & 21.7 \\
Sucrose $^{1}$ & 43.3 \\
Corn oil $_{\text {AIN-93M mineral } \text { mix }^{2}}$ & 5.0 \\
${\text { AIN-93VX vitamin } \text { mix }^{2}}_{\text {Cellulose }^{1}}$ & 3.5 \\
Choline chloride $^{2}$ & 1.0 \\
\hline
\end{tabular}

${ }^{1}$ Supplied by Oriental Yeast, Tokyo, Japan.

${ }^{2}$ Supplied by Nihon Nosan K.K., Yokohama, Japan (40).
(20). At $10 \mathrm{~min}$ after injection, rats were quickly decapitated. Tissue samples were homogenized with 10 volumes of cold $0.2 \mathrm{~mol} / \mathrm{L}$ perchlolic acid and then centrifuged at $2,800 \times g$ for $15 \mathrm{~min}$ at $4^{\circ} \mathrm{C}$. The supernatant was used for the measurements of specific activity after adjusting the $\mathrm{pH}$ to $6.0-7.0$ with saturated potassium citrate. The precipitate containing protein was washed three times with $5 \mathrm{~mL}$ of $0.2 \mathrm{~mol} / \mathrm{L}$ perchloric acid, suspended in $10 \mathrm{~mL}$ of $0.3 \mathrm{~mol} / \mathrm{L} \mathrm{NaOH}$ and incubated at $37^{\circ} \mathrm{C}$ for $1 \mathrm{~h}$.

Protein-bound phenylalanine was obtained by reprecipitating the protein with $2 \mathrm{~mL}$ of $2 \mathrm{~mol} / \mathrm{L}$ perchlolic acid, washing the pellet with $5 \mathrm{~mL}$ of $0.2 \mathrm{~mol} /$ perchloric acid twice and hydrolyzing the protein in $10 \mathrm{~mL}$ of $6 \mathrm{~mol} / \mathrm{L} \mathrm{HCl}$ for $24 \mathrm{~h}$ at $110^{\circ} \mathrm{C}$. The $\mathrm{HCl}$ was evaporated to dryness, and the amino acids were dissolved in citrate buffer $(\mathrm{pH}$ 6.3). The determination of the specific radioactivity of $\left[{ }^{3} \mathrm{H}\right]$ phenylalanine involved its enzymatic conversion into phenetylamine by tyrosine decarboxylase, followed by a radioactivity count (LS 5000TD, Beckman Japan, Tokyo, Japan) and fluorometric determination (F-3000, Hitachi Co., Tokyo, Japan). The assay for phenetylamine was measured according to the method of Suzuki and Yagi (24). To $1.0 \mathrm{~mL}$ of the solution of phenetylamine, $2.5 \mathrm{~mL}$ of $1 \mathrm{~mol} / \mathrm{L}$ potassium phosphate (pH 8.0), $0.5 \mathrm{~mL}$ of $2 \mathrm{mmol} / \mathrm{L}$ leucylalanine and $1 \mathrm{~mL}$ of $50 \mathrm{mmol} / \mathrm{L}$ ninhydrin were added. The samples were incubated at $60^{\circ} \mathrm{C}$ for $1 \mathrm{~h}$, and the fluorescence at $495 \mathrm{~nm}$ (excitation $390 \mathrm{~nm}$ ) was measured.

In a preliminary experiment, we determined whether the method of Garlick et al. (20) could be used to measure the rate of protein synthesis in the brain under this experimental condition. Specific radioactivities of free phenylalanine in the plasma, cerebral cortex and cerebellum in rats of the three groups were constant in each tissue (The data are not shown). Moreover, the values were also not significantly different among the plasma, cerebral cortex and cerebellum, indicating that the precursor pool of labeled phenylalanine was not altered. In our previous report (7), the decrease in labeling of free phenylalanine at 3, 5 and $10 \mathrm{~min}$ in the brain was not significant after an injection of a large dose of $\left[{ }^{3} \mathrm{H}\right]$ phenylalanine. Therefore, the protein synthesis rates for brain regions were calculated for animals killed at a single time point of 10 min after intravenous administration of the radioisotope.

The fractional rates of protein synthesis (Ks) for brain regions were calculated from the specific radioactivity of phenylalanine in protein $(\mathrm{Sb})$ at $10 \mathrm{~min}$ and the specific radioactivity of free phenylalanine in the tissue (Sa) at $10 \mathrm{~min}$. The formula for calculating $\mathrm{Ks}$ has been given by Garlick et al. (20), i.e.

$\mathrm{Ks}(\% / \mathrm{d})=\mathrm{Sb} \times 100 / \mathrm{Sa} \times t$

where $t$ is the incorporation time in days.

The RNA activity was calculated by dividing the fractional rate of protein synthesis by the RNA/protein ratio. The absolute protein synthesis was calculated by multiplying the fractional rate of protein synthesis by the protein contents of tissues. 
Table 2. Effect of growth hormone treatment on body weight gain, brain region relative weights and plasma concentration of growth hormone in hypophysectomized rats. ${ }^{1}$

\begin{tabular}{|c|c|c|c|c|}
\hline & Control & Hypophysectomy & $\begin{array}{c}\text { Hypophysectomy } \\
+\mathrm{GH}^{2}\end{array}$ & $\begin{array}{c}\text { Pooled } \\
\text { SE }\end{array}$ \\
\hline Body weight gain 3 (g/7 d) & $15.8^{\mathrm{a}}$ & $-1.4^{\mathrm{b}}$ & $20.8^{\mathrm{a}}$ & 2.6 \\
\hline Final body weight $(\mathrm{g})$ & $404^{\mathrm{a}}$ & $306^{\mathrm{b}}$ & $322^{b}$ & 11 \\
\hline Food intake $(\mathrm{g} / \mathrm{d})$ & $20.2^{\mathrm{a}}$ & $12.6^{\mathrm{b}}$ & $12.7^{b}$ & 0.4 \\
\hline \multicolumn{5}{|c|}{ Tissue weight (g/100 g body weight) } \\
\hline Cerebral cortex & 0.117 & 0.120 & 0.119 & 0.003 \\
\hline Cerebellum & 0.097 & 0.099 & 0.097 & 0.002 \\
\hline Hipppocampus & 0.034 & 0.036 & 0.037 & 0.002 \\
\hline Brain stem & 0.046 & 0.044 & 0.044 & 0.002 \\
\hline \multicolumn{5}{|l|}{ Tissue protein (mg/g tissue) } \\
\hline Cerebral cortex & 133 & 143 & 148 & 6 \\
\hline Cerebellum & 146 & 147 & 142 & 6 \\
\hline Hippocampus ${ }^{4}$ & 142 & 137 & 140 & \\
\hline Brain stem ${ }^{4}$ & 139 & 145 & 157 & \\
\hline Plasma GH ( $\mu \mathrm{g} / \mathrm{L}$ plasma $)$ & $23.9^{\mathrm{a}}$ & $4.0^{\mathrm{b}}$ & $24.4^{\mathrm{a}}$ & 2.0 \\
\hline
\end{tabular}

\footnotetext{
${ }^{1}$ Values are means and pooled SE, $n=6$. Means with different superscript letters are significantly different $(p<0.05)$.

${ }^{2}$ Growth hormone.

${ }^{3}$ Initial body weight of rats was 290-390 g.

${ }^{4}$ Data were obtained by a single analysis of pooled samples from six rats.
}

Table 3. Effect of growth hormone treatment on fractional and absolute protein synthesis rates in brain regions of hypophysectomized rats. ${ }^{1}$

\begin{tabular}{|c|c|c|c|c|}
\hline & Control & Hypophysectomy & $\begin{array}{l}\text { Hypophysectomy } \\
+\mathrm{GH}^{2}\end{array}$ & $\begin{array}{l}\text { Pooled } \\
\text { SE }\end{array}$ \\
\hline \multicolumn{5}{|c|}{ Protein synthesis $(\mathrm{Ks})^{3}(\% / \mathrm{d})$} \\
\hline Cerebral cortex & $20.1^{\mathrm{a}}$ & $15.4^{\mathrm{b}}$ & $20.2^{\mathrm{a}}$ & 1.1 \\
\hline Cerebellum & $21.9^{\mathrm{a}}$ & $15.5^{\mathrm{b}}$ & $21.2^{\mathrm{a}}$ & 0.8 \\
\hline Hippocampus $^{4}$ & 18.7 & 15.6 & 20.4 & \\
\hline Brain stem ${ }^{4}$ & 32.4 & 27.6 & 36.4 & \\
\hline \multicolumn{5}{|c|}{ Absolute protein synthesis (mg protein synthesized/(tissue $\cdot d)$ ) } \\
\hline Cerebral cortex & $12.5^{\mathrm{a}}$ & $8.1^{\mathrm{b}}$ & $11.3^{\mathrm{a}}$ & 0.6 \\
\hline Cerebellum & $12.4^{\mathrm{a}}$ & $6.9^{\mathrm{b}}$ & $10.9^{\mathrm{a}}$ & 0.6 \\
\hline Hippocampus $^{4}$ & 3.6 & 2.3 & 3.4 & \\
\hline Brain stem ${ }^{4}$ & 8.3 & 5.4 & 8.1 & \\
\hline
\end{tabular}

Statistical analysis. The means and pooled SE are reported. Duncan's multiple range test was used to compare means after one-way $\operatorname{ANOVA}(25,26)$. Linear regression analysis was used to assess the relationship between the rate of protein synthesis and RNA activity, and between the rate of protein synthesis and RNA concentration (26). Differences were considered significant at $p<0.05$. In the hippocampus and brain stem, the rates of protein synthesis were determined from a pool of each region.

\section{RESULTS}

The hypophysectomized rats without GH treatment gained less body weight than the sham-operated control group or hypophysectomized rats treated with $\mathrm{GH}$, which did not differ (Table 2). The control group consumed more food than did either group of hypophysectomized rats, which did not differ. The relative weights of the various brain regions did not differ among groups. Compared with the untreated hypophysectomized rats, the plasma concentration of GH was significantly higher in that of hypophysectomized rats treated with GH or of the control rats.

Hypophysectomy alone resulted in significantly lower fractional (Ks) and absolute rates of protein synthesis in some brain regions, such as the cerebral cortex and cerebellum than did treatment with hypophysectomy plus $\mathrm{GH}$ or no treatment (control) (Table 3). In pooled samples of hippocampus and brain stem, these rates also were lower in the hypophysectomized rats. 
Table 4. Effect of growth hormone treatment on RNA concentrations and RNA activities in brain regions of hypophysectomized rats. ${ }^{1}$

\begin{tabular}{|c|c|c|c|c|}
\hline & Control & Hypophysectomy & $\begin{array}{c}\text { Hypophysectomy } \\
+\mathrm{GH}^{2}\end{array}$ & $\begin{array}{l}\text { Pooled } \\
\text { SE }\end{array}$ \\
\hline \multicolumn{5}{|c|}{ RNA/protein (mg/g) } \\
\hline Cerebral cortex & $13.2^{\mathrm{a}}$ & $12.3^{\mathrm{b}}$ & $12.4^{\mathrm{b}}$ & 0.2 \\
\hline Cerebellum & $12.9^{\mathrm{a}}$ & $11.0^{\mathrm{b}}$ & $11.4^{\mathrm{b}}$ & 0.3 \\
\hline Hippocampus $^{3}$ & 10.9 & 11.1 & 10.8 & \\
\hline Brain stem ${ }^{3}$ & 11.3 & 10.7 & 10.8 & \\
\hline \multicolumn{5}{|c|}{ RNA activity (g protein synthesized/(g RNA $\cdot \mathrm{d})$ ) } \\
\hline Cerebral cortex & $15.2^{\mathrm{a}}$ & $12.5^{\mathrm{b}}$ & $16.3^{\mathrm{a}}$ & 0.7 \\
\hline Cerebellum & $17.0^{\mathrm{a}}$ & $14.1^{\mathrm{b}}$ & $18.6^{\mathrm{a}}$ & 0.6 \\
\hline Hippocampus ${ }^{3}$ & 17.2 & 14.1 & 18.9 & \\
\hline Brain stem $^{3}$ & 28.7 & 25.8 & 33.7 & \\
\hline
\end{tabular}

The RNA activity [g protein synthesized/(g of RNA $\cdot d)$ ] in the brain regions was significantly lower in the untreated hypophysectomized group than in the control or hypophysectomy plus GH groups (Table 4). Correlations between the fractional rate of protein synthesis and RNA activity were significant in the cerebral cortex $(r=0.967, p<0.001)$ and cerebellum $(r=0.885$, $p<0.001)$. Compared with the control group, lower RNA concentrations (mg RNA/g protein) of brain regions were observed in either group of hypophysectomized rats, which did not differ (Table 4). The fractional rate of protein synthesis was correlated to the RNA concentration in the cerebral cortex $(r=0.562, p<0.05)$ and cerebellum $(r=0.630, p<0.05)$.

\section{DISCUSSION}

More research concerning age-related changes in brain composition and function (e.g., nutrient metabolism), is necessary to understand the modulating effects of nutritional factors (27). In the previous studies, we demonstrated that the protein synthesis in brain regions and plasma concentration of GH decreased with a decrease in the quantity and quality of dietary protein in aged rats (12-14). Recent studies have shown that GH may affect functions related to the central nervous system. It is well established that a decline of cognitive function with aging is paralleled with decreased blood levels of GH (16). However, little information is available on the effects of $\mathrm{GH}$ on the rate of brain protein synthesis during GH deficiency. We hypothesized that the rate of brain protein synthesis would increase in hypophysectomized rats with $\mathrm{GH}$ treatment.

Hypophysectomized rats had reduced fractional rates of protein synthesis in brain regions, whereas treatment of GH reversed the effect of hypophysectomy (Table 3). The changes in the brain protein synthesis likely depend on the body GH concentration. GH increased the transcription rate (16) and translation rate (15). In weaned rats, a reduction with age in protein synthesis in the brain and skeletal muscle was related to a fall in
RNA concentration $(10,11)$. However, a positive correlation between the rate of protein synthesis and RNA activity was found in the brain of aged rats when the dietary quantity and quality were manipulated (12, 13). In the present study, hypophysectomy decreased the RNA concentrations; however, GH treatment did not reverse the effect of hypophysectomy. In the brain regions, RNA activities, rather than RNA concentrations, in the hypophysectomy plus GH and sham-operated control groups were greater than those in the hypophysectomized group (Table 4). Hypophysectomy and treatment with GH may have controlled RNA activity and been one of the factors affecting brain protein synthesis in aged rats. Our previous results strongly indicated that the quantity and quality of dietary protein might regulate the concentration of $\mathrm{GH}$ and control the rates of protein synthesis in the brain regions of aged rats (12-14). Therefore, the concentration of GH may be at least partly related to the mechanism by which dietary protein affects brain protein synthesis in aged rats.

Little information is available on the mechanism by which GH affects RNA activity in the brain of hypophysectomized aged rats. We previously reported that the aggregation of polyribosomes in the brain of weaned and aged rats decreased with a decrease in dietary protein, and that there was a correlation between the polysomal profile and RNA activity $(7,28)$. Many investigations suggested that the polysomal profile in tissues represented the changes in the translational phase of protein synthesis $(7,29)$. In both liver and muscle, the stimulation of protein synthesis caused by dietary protein is reported to be mediated by the increase in the initiation of mRNA translation (30). Kato (15) suggested that GH might stimulate the translational phase of tissue protein synthesis. Measurement of the initiation factors of mRNA translation and the ribosomal aggregation in the brain should be included in the further studies for the effect of GH on brain protein synthesis in hypophysectomized aged rats. Recently, Le Greves et al. 
(16) suggested that GH induced the gene expression of the $N$-methyl-D-aspartate receptor in the hippocampus of rats. In the present study, we did not determine the concentration of mRNA in the brain regions. This is another possibility to consider in further examination of the mechanism by which hypophysectomy and GH treatment alter brain protein metabolism.

In the previous report (14), we found that the ingestion of a higher quantity and quality of dietary protein increased the concentration of most essential amino acids including branched chain amino acids in the brain and plasma. Koie et al. (31) and Lyou et al. (32) reported that the addition of lysine or methionine to a low-gluten diet or to a low-soy protein diet, respectively, increased the protein synthesis rates in the brains of aged rats. Recently, leucine has been shown to be the most potent of the amino acids in enhancing the initiation phase of mRNA translation (33). Yoshizawa et al. $(34,35)$ demonstrated that leucine stimulated the translation initiation by inhibiting the translational repressor, eukaryotic initiation factor (eIF) 4E-binding protein 1 , in the liver and skeletal muscle. Therefore, the decrease of protein synthesis rates in the brain resulting from the lower quantity and quality of dietary protein may be due to the dietary-limiting amino acids, which were at low levels in the brain and plasma. The role of amino acids on the initiation factors of mRNA translation in the brain should be included in further studies of the effect of dietary protein on the brain protein synthesis in older rats.

A deficiency of $\mathrm{GH}$ also affects brain function. $\mathrm{GH}$ replacement therapy has improved psychological capabilities in young as well as adult GH-deficient patients (36). Treatment of adult GH-deficient patients with human $\mathrm{GH}$ is reported to improve the cognitive efficiency and memory function $(37,38)$. The GH has been found to facilitate the long-term memory and the extinction response as recorded in a behavioral assay in rats (19). In the present study, the treatment with GH resulted in higher fractional rates of brain protein synthesis in hypophysectomized aged rats. As mentioned above, GH has been shown to induce the gene expression of hippocampal $N$-methyl-D-aspartate receptor, coinciding with improved learning and memory capabilities (16). These results suggested that there was a positive relationship between the brain function and brain protein synthesis when GH status was manipulated. Therefore, the direct effects of $\mathrm{GH}$ on the brain protein synthesis in aged rats are of nutritional importance.

The food intake of the two hypophysectomized groups was significantly lower than that of the shamoperated control group (Table 2). However, the rate of brain protein synthesis and body weight gains in hypophysectomized rats were less than that of the control and hypophysectomy plus GH groups. The GH-binding receptor has been identified in the brains of humans and rats (39). GH is well known as the anabolic hormone in protein metabolism. These results strongly suggested that GH deficiency and GH, rather than food intake, directly affect brain protein synthesis. Previously we found that physiological treatment of corticosterone to adrenalectomized rats increased the food intake (unpublished data). The adrenocorticotropic hormone $(\mathrm{ACTH})$ is also secreted by the pituitary gland. In hypophysectomized aged rats, the deficiency of adrenocorticotropic hormone may affect the food intake.

The present results indicate that brain protein synthesis was affected by GH in hypophysectomized aged rats as evaluated by protein synthesis rates, and suggested that the changes in concentration of $\mathrm{GH}$ are at least partly involved in regulating the brain protein synthesis in aged rats given proteins different in quantity and quality.

\section{Acknowledgments}

The authors are grateful to M. Harada and T. Hijikata for their valuable technical assistance. This study is supported in part by a grant from the Iijima Memorial Foundation for the Promotion of Food Science and Technology, Japan.

\section{REFERENCES}

1) Goldspink DF, Lewis SEM, Kelly FJ. 1984. Protein synthesis during the developmental growth of the small and large intestine of the rat. Biochem J 217: 527-534.

2) Lewis SEM, Kelly FJ, Goldspink DF. 1984. Pre- and postnatal growth and protein turnover in smooth muscle, heart and slow- and fast-switch skeletal muscles of the rat. Biochem J 217: 517-526.

3) Millward DJ, Garlick PJ, Nnanyelugo DO, Waterlow JC. 1976. The relative importance of muscle protein synthesis and breakdown in the regulation of muscle mass. Biochem J 156: 185-188.

4) Symmons RA, Maquire EJ, Rogers QR. 1972. Effect of dietary protein and feeding schedule on hepatic polysome pattern in the rat. J Nutr 102: 639-646.

5) Yokogoshi H, Sakuma Y, Yoshida A. 1980. Effect of dietary protein quality and quantity on hepatic polyribosome profiles in rats. J Nutr 110: 1347-1353.

6) Beverly JL III, Gietzen DW, Rogers QR. 1991. Protein synthesis in the prepyriform cortex: effects on intake of an amino acid-imbalanced diet by Sprague-Dawley rats. J Nutr 121: 754-761.

7) Yokogoshi H, Hayase K, Yoshida A. 1992. The quality and quantity of dietary protein affect brain protein synthesis in rats. J Nutr 122: 2210-2217.

8) Attaix D, Aurosseau E, Bayle G, Rosolowska-Huszcz D, Arnal M. 1988. Respective influences of age and weaning on skeletal and visceral muscle protein synthesis in the lamb. Biochem J 256: 791-795.

9) Goldspink DF, Kelly FJ. 1984. Protein turnover and growth in the whole body, liver and kidney of the rat from the foetus to senility. Biochem J 217: 507-516.

10) Waterlow JC, Garlick PJ, Millward DJ. 1978. Protein Turnover in Mammalian Tissues and in the Whole Body, p 529-594. North-Holland, Amsterdam.

11) Hayase K, Yokogoshi H. 1994. Age affects brain protein synthesis in rats. J Nutr 124: 683-688.

12) Hayase K, Koie M, Yokogoshi H. 1998. The quantity of dietary protein affects brain protein synthesis rate in aged rats. J Nutr 128: 1533-1536. 
13) Koie M, Tanaka M, Hayase K, Yoshida A, Yokogoshi H. 1999. Effect of dietary protein quality on the brain protein synthesis rate in aged rats. J Nutr Sci Vitaminol 45: 481-489.

14) Ohsumi M, Shi X, Tuchiya T, Tujioka K, Lyou S, Hayase K, Yokogoshi H. 2007. The role of growth hormone and amino acids on brain protein synthesis in aged rats given proteins of different quantity and quality. Amino Acids 32: 247-253.

15) Kato H. 2002. Molecular biology of protein metabolism. In: Molecular Nutrition (Kakinuma J, ed), p 50-64. Koseikan, Tokyo.

16) Le Greves M, Steensland P, Le Greves P, Nyberg F. 2002. Growth hormone induces age-dependent alteration in the expression of hippocampal growth hormone receptor and N-methyl-D-aspartate receptor subunits gene transcripts in male rats. Proc Natl Acad Sci USA 99: 7119-7123.

17) Burman P, Hetta J, Wide L, Mansson JE, Ekman R, Karlsson FA. 1996. Growth hormone treatment affects brain neurotransmitters and thyroxine. Clin Endoclinol 44: 319-324.

18) Johansen PB, Flyvbjerg A, Michael Wilken M, Malmlöf K. 2000. Comparison of methods of analysis of body composition in hypophysectomized rats treated with rat growth hormone. Growth Horm IGF Res 10: 342-348.

19) Schneider-Rivas S, Rivas-Arancibia S, Vazquez-Pereyra F, Vezquez-Sandval R, Borgonio-Perez G. 1995. Modulation of long-term memory and extinction responses induced by growth hormone (GH) and growth hormone releasing hormone (GHRH) in rats. Life Sci 56: PL433441.

20) Garlick PJ, McNurlan M A, Preedy VR. 1980. A rapid and convenient technique for measuring the rate of protein synthesis in tissues by injection of $\left[{ }^{3} \mathrm{H}\right]$ phenylalanine. Biochem J 192: 719-723.

21) Reinstein DK, Isaacson RI, Dunn AJ. 1979. Regional change in 2-deoxyglucose uptake after neocortical and hippocampal destruction. Brain Res 175: 392-397.

22) Lowry OH, Rosebrough NJ, Farr AL, Randall RJ. 1951. Protein measurement with the Folin phenol reagent. $J$ Biol Chem 193: 265-275.

23) Fleck A, Munro HN. 1962. The precision of ultraviolet absorption measurements in the Schmidt-Thannhauser procedure for nucleic acid estimation. Biochim Biophys Acta 55: 571-583.

24) Suzuki O, Yagi K. 1976. A fluorometric assay for $\beta$ phenetylamine in rat brain. Anal Biochem 75: 192-200.

25) Duncan DB. 1955. Multiple range and multiple F tests. Biometrics 11: 1-42.

26) Snedecor GW, Cochran WG. 1967. Statistical Methods, 6th ed, p 135-171. Iowa State University Press, Ames.

27) Smiciklas-Wright H. 1990. Aging. In: Present Knowledge in Nutrition (Brown ML, ed), 6th ed, p 333-340. International Life Sciences Institute, Nutrition Foundation, Washington DC.

28) Hirano E, Lyou S, Tujioka K, Tanaka M, Hayase K, Okuyama S, Yokogoshi H. 2002. Effects of quantity and quality of dietary protein on the brain polysome profile in aged rats. Biosci Biotechnol Biochem 66: 351-355.

29) Flaim KE, Liao WSL, Peavy DE, Taylor JM, Jefferson LS. 1982. The role of amino acids in the regulation of protein synthesis in perfused liver. II. Effects of amino acid deficiency of peptide chain initiation, polysomal aggregation, and distribution of albumin mRNA. J Biol Chem 257: 2939-2946.

30) Yoshizawa F, Kimball SR, Vary TC, Jefferson LS. 1998. Effect of dietary protein on translation initiation in rat skeletal muscle and liver. Am J Physiol 275: E814E820.

31) Koie M, Tanaka M, Hayase K, Yokogoshi H. 2000. Effects of adding dietary lysine to a low gluten diet on the brain protein synthesis rate in aged rats. Biosci Biotechnol Biochem 64: 1466-1471.

32) Lyou S, Tujioka K, Hirano E, Mawatari Y, Hayase K, Okuyama S, Yokogoshi H. 2004. Effect of adding dietary methionine to a low soy protein diet on the brain protein synthesis rate in ovariectomized female rats. Nutr Neurosci 7: 185-190.

33) Anthony JC, Yoshizawa F, Gautsch Anthony T, Vary TC, Jefferson LS, Kimball SR. 2000. Leucine stimulates translation in skeletal muscle of postabsorptive rats via a rapamycin-sensitive pathway. J Nutr 130: 24132419.

34) Yoshizawa F, Sekizawa H, Hirayama S, Hatakeyama A, Nagasawa T, Sugahara K. 2001. Time couse of leucineinduced 4E-BP1 and S6K1 phosphorylation in the liver and skeletal muscle of rats. J Nutr Sci Vitaminol 47: 311-315.

35) Yoshizawa F, Sekizawa H, Hirayama S, Yamazaki Y, Nagasawa T, Sugahara K. 2004. Tissue-specific regulation of 4E-BP1 and S6K1 phosphorylation by $\alpha$-ketoisocaproate. J Nutr Sci Vitaminol 50: 56-60.

36) Burman P, Broman JE, Hetta J, Wiklund I, Erfurth EM, Hagg E, Karlsson FA. 1995. Quality of life in adults with growth hormone $(\mathrm{GH})$ deficiency: response to treatment with recombinant human $\mathrm{GH}$ in a placebo-controlled 21-month trial. J Clin Endocrinol Metab 80: 35853590.

37) Deijen JB, de Boer H, van der Veen EA. 1998. Cognitive changes during growth hormone replacement in adult men. Psychoneuroendocrinology 23: 45-55.

38) Gibney J, Wallace JD, Spinks T, Schnorr L, Ranicar A, Cuneo RC, Lockhart S, Burnand KG, Salomon F, Sonksen PH, Russel-Jones D. 1999. The effects of 10 years of recombinant human growth hormone $(\mathrm{GH})$ in adult GH-deficient patients. J Clin Endocrinol Metab 84: 2596-2602.

39) Lai Z, Roos P, Zhai Q, Olsson Y, Fholenhag K, Larsson C, Nyberg F. 1993. 20 Age-related reduction of human growth hormone-binding sites in the human brain. Brain Res 621: 260-266.

40) American Institute of Nutrition. 1993. AIN-93 purified diets for laboratory rodents: final report of the American Institute of Nutrition Ad Hoc Writing Committee on the reformulation of the AIN-76A rodent diet. J Nutr 123: 1939-1951. 